\title{
El Celoso Paranoico en Ciertas Historias de Machado de Assis
}

Joaquim Maria Machado de Assis, como hombre y como autor, siempre demostró un alto interés por los conflictos internos del hombre. Fue un investigador diligente de los móviles que llevan al ser humano a actuar en distintas formas, y ciertas pasiones merecieron su especial atención. Después de leer y estudiar su obra se puede comprobar que los celos, y la persona que se encuentra subyugada por ellos, nunca cesó de interesarle. Son muchísimos los cuentos en donde el protagonista es víctima de esta pasión. Conviene, no obstante, aclarar que entre estos personajes hay algunos que se destacan y presentan un aspecto sumamente interesante dentro del grupo. Se trata, en particular, del individuo cuyos celos se convierten en una condición patológica que afecta a su personalidad y a sus acciones. Son celos que perjudican tanto al individuo que los padece o como a los que lo rodean, especialmente a la persona que, sin percibirlo, ha sido causa de semejante condición. Esta anormalidad es todavía más grave en los casos en que los celos son completamente infundados y la mujer que es víctima de ellos es inocente. Este factor contribuye a comunicar la idea de que ésta es, en verdad, una condición patológica.

Antes de proceder al estudio de algunos de estos personajes, señalemos a su representante antonomástico; nos teferimos al protagonista de la novela que, según la opinión de muchos críticos, es la creación máxima de Machado de Assis: Dom Casmurro. Esta novela ha sido objeto de un penetrante estudio por Helen Caldwelli'; de manera que nos

${ }^{1}$ Helen Caldwell, The Brazilian Otbello of Machado de Assis (Berkeley: University of California Press, 1960). Es esta obra un extenso estudio de Dom Casmurro, en el cual la autora, apartándose de la opinión de muchos críticos brasileños, ha tomado la defensa de Capitu. Por medio de ui detenido examen de la novela, y basándose en la semejanza que establece entre Dom Casmurro y Othello, la autora ha defendido, con bastante éxito, la inocencia de Capitu. 
limitaremos aqui a mencionar sus rasgos más generales y a hacer algunos comentarios, ya que está relacionada tan de cerca con los personajes que nos proponemos examinar.

Machado de Assis logró crear lo que podría clasificarse como un misterio perfecto, y logró despistar completamente a toda una legión de lectores, inclusive a la mayoría de críticos y estudiosos de su obra, los cuales son unánimes en su veredicto concerniente a Capitu, la esposa del celoso Bentinho. Esta opinión puede resumirse en las líneas escritas por Eugênio Gomes: "Capitu-carne, mundo, oceano, onda-é um símbolo do $\mathrm{Mal}$, com ardis e atrativos de mulher..."2

El libro es una peregrinación por el alma atormentada de Bento Santiago, penetrada por el virus de los celos desde muy joven. Celos de Capitu, su vecina, luego su novia y después su esposa. Bento muy pronto se dio cuenta de la superioridad intelectual de Capitu, de su fuerte personalidad y de su carácter sobresaliente. Su amigo, Escobar, es también superior a él; más inteligente, más fuerte y más atractivo que el raquítico Bento. Como si esto no fuera suficiente, Bento esta siempre sometido a la voluntad de su madre, mujer de recio carácter, que ha destinado a su hijo, desde antes de nacer, a la vida religiosa. Bento vence este obstáculo con la ayuda de Capitu, con la cual luego contrae matrimonio. Es inevitable, sin embargo, que después de casado, los celos, que habrían hecho su aparición poco tiempo antes, vengan a adueñarse de su alma y que en su imaginación ligue a los dos seres que considera superiores a él. Es importante aquí notar que es el mismo Bentinho quien cuenta su historia; de manera que todas las insinuaciones, todas las conclusiones que él hace con respecto a su mujer, no son dignas de confianza. Capitu muere en el exilio que su marido le ha impuesto, y el hijo, secretamente repudiado por Bento por creerlo hijo de Escobar, muere poco después en una expedición arqueológica. Este acontecimiento causa gran alivio en el espíritu de Bento, quien, por eso, el día que supo la noticia comió bien y fue al teatro.

En un artículo escrito por Peter Novotny, psiquiatra del Meningar Memorial Hospital, el autor comenta que en 1900 Freud publicó su

2 Eugênio Gomes, Machado de Assis (Rio de Janeiro: Livraria São José, 1958), p. 160. El mismo autor ha publicado el siguiente libro: O Enigma de Capitu (Rio de Janeiro: Livraria José Olympio Editôra, 1967). Este libro es un minucioso estudio basado en Dom Casmurro, en el cual el autor ha examinado a Capitu y a Bento desde diferentes ángulos y puntos de vista; ofrece conclusiones esclarecedoras y revela que el señor Gomes ha modificado un tanto su opinión sobre la personalidad de ambos protagonistas: Ya no se habla de Capitu como el símbolo del mal, y las reflexiones de Bento son considera. das "as rẹflexóes de uta cétẹbro enfềma" (p. 138). 
libro sobre la interpretación de los sueños, fecha que coincide con la publicación de Dom Casmurro:

In the same year, in quite a different part of the world a nove1 was finished which displayed an intuitive psychological awareness of and at times considerable similarity to some of the discoveries of psychoanalysis. What is more remarkable here is that the author, Machado de Assis, could not have known of Freud. ${ }^{3}$

Más adelante, comentando sobre los celos de Bentinho, nos dice el mismo autor:

Insidiously and in a manner which displays all the marks of a jealousy paranoia, the conviction develops in the hero that his friend Escobar had been Capitu's lover and the father of the child, as the child has a physical resemblance to Escobar. The delusion leads to Bentinho's turning away from wife and son, abandoning and subsequently destroying them, and to the transformation of the hero's personality into Dom Casmurro, the isolated, withdrawn, suspicious, morose man. ${ }^{4}$

El señor Novotny ha examinado cuidadosamente esta obra desde el punto de vista clínico, y ofrece la conclusión de que, por la manera en que los celos se manifiestan, el libro describe un conflicto de identificación sexual, provocado en parte y según estudios recientes, por la influencia de una madre dominante y la ausencia de la figura del padre. Dice el mencionado autor: ". . the book shows clearly a coin. cidence of strong homosexual feelings with a "pathological' jealousy."

El veredicto final respecto a la culpabilidad o inocencia de Capitu es, en cierto modo, 'dejado a la discreción del último juez: el lector. Sin embargo, después de que el mismo Bento Santiago, al contar su

3 peter Novotny, "A Poetic Corroboration of Psychoanalysis", American Imago, XXII (Spring-Sunmer, 1965), p. 40.

4 Ibid., pp. $40-41$.

5 Ibtd., p. 45. En conexión con este artículo del señor Novotny, es preciso nencionar de nuevo el libro O Enigma de Capitu, en el cual el señor Gomes comenta: "Antes de qualquer outro aspecto, o que existiu du conêço em Bentinho foi una esquisita confusão de sentimentos relativamente a Escobar" (p. 116). Y como conclusión a sus observaciones sobre las relaciones que existían entre los dos amigos, dice el mismo autor: "Não há dúvida, a ascendência de Escobar sôbre Bentinho, positivada desde os primeiros contatos, era invencível, porque assentava em um sentimento extremamente complexo. Um psicanalista explicá-lo-á melhor" (p. 118). 
historia, ha desacreditado la veracidad y la exactitud de su buen juicio presentándose a nuestros ojos como un individuo mezquino, envidioso y obcecado por los celos, la conclusión lógica es que la infidelidad de la esposa es real sólo en la mente febril de Dom Casmurro.

En sus cuentos Machado de Assis nos dio una serie de personajes que se encuentran en situaciones análogas, es decir, dominados por un frenesí de celos y víctimas de una condición patológica que en muchos casos los conduce a la violencia. En "A Mulher de Prêto," escrito en 1868, Meneses es una persona grave y triste, descrita por su amig. Estêvão como un hombre que sufre intensamente y en silencio:

Tinha os olhos negros e um pouco amottecidos; adivinhavase porém que deviam ter sido vivos e ardentes... Não tinha rugas de velhice; tinha uma ruga na testa, entre as sobrancelhas, indício de concentração de espírito, e não vestígio do tempo."

A medida que la historia se desarrolla y nos damos cuenta del amor de Estêvão por una bella viuda, descubrimos también que esta señon es en realidad la esposa de Meneses, repudiada por éste por considerarla culpable de adulterio. Nunca tuvo Meneses pruebas concretas de la culpa de su esposa, ni se preocupó por averiguarlas, pero se negó a creer sus afirmaciones de inocencia:

...uma carta e um retrato eram os indícios; ela negou, mas explicou-se mal; o marido separou-se e mandou-a para o Rio de Janeiro.?

La carta y el retrato acusadores pertenecían a una amiga de Madalena Meneses, cuyas confidencias indiscretas no quiso Madalena divulgar. Pero aún cuando Meneses más tarde comprueba la inocencia de su esposa por medio del amigo Estêvão, rehusa admitir el error que cometió, castigando de tal forma a una mujer inocente:

- Meu caro Estêvão, a mulher de César nem deve ser suspeitada. Acredito em tudo; mas o que está feito, está feito. ${ }^{8}$

Sin embargo, gracias a los esfuerzos del amigo, se efectúa por fin la reconciliación entre Meneses y su esposa.

6 Machado de Assis, "A Mulher de Prêto", Contos Fluminenses, I (São Paulo: Editôra Mérito, S. A., 1962), pp. 98-99.

7 Ibid., p. 126

8 Ibid., p. 133. 
En otra historia escrita cinco años más tarde, "O Relógio de Ouro", podemos apreciar la personalidad y las reacciones de un marido predispuesto a sospechar de la fidelidad de la esposa por cualquier causa. Luis Negreiros llega un día a su casa y encuentra en su alcoba un reloj de oro, nuevo y elegante; es un reloj de hombre. Sabiendo que no es suyo, la sospecha de que su esposa ha cometido una indiscreción se adueña de él casi en el mismo instante:

Por êste motivo, e outros que são óbvios, comprendeerá o leitor que o espôso de Clarinha se atirasse sôbre uma cadeira, puxasse raivosamente os cabelos, batesse com o pé no chão, e lançasse o relógio e a corrente por cima da mesa. ${ }^{9}$

La furia de Negreiros aumenta cuando su esposa asegura en voz baja y dando muestras de gran abatimiento, que no sabe nada al respecto. Violentamente Luis arroja una silla al suelo y amenaza hacer lo mismo con la esposa:

Luis Negreiros passeava cada vez mais agitado, revolvendo os olhos nas órbitas, e parecendo prestes a atirar-se sôbre a infeliz espôsa. ${ }^{10}$

La llegada del padre de Clarinha interrumpe esta escena. El suegro le recuerda al yerno que su cumpleaños es al día siguiente. Luis, eufórico, piensa entonces que el reloj es un regalo de su esposa. Sin embargo, al tratar de agradecerle, Luis comprueba, consternado, que Clatinha se pone todavía más triste y desesperada con esta actitud del esposo. Inmediatamente renacen sus sospechas y la situación se hace más tensa; Luis se dirige a interrogar de nuevo a su esposa en un tono amenazador:

-Clarinha, disse êle, êste momento é solene. Respondes-me ao que te pregunto desde esta tarde?

A môç̧a não respondeu.

-Reflete Bem, Clarinha, continuou o marido. Podes arriscar a tua vida.

A môça levantou os hombros.

Uma nuvem passou pelos olhos de Luis Negreiros. O infeliz

9 Machado de Assis, "O Relógio de Ouro", Histórias da Meia-Noite (São Paulo: Editôra Mérito, S. A., 1962), p. 210.

10 Ibid., p. 213. 
marido lançou as mãos ao colo da espôsa e rugiu:

-Responde, demônio, ou morres!11

Viéndose amenazada de esta manera, Clarinha explica que un mensajero llevó a casa el reloj y un mensaje. Negreiros lee el mensaje y se da cuenta de que el reloj es un regalo de su amante. La tristeza y el abatimiento de Clarinha, interpretados por el marido como señal de culpabilidad, se comprenden entonces con claridad. Como explica el autor, Clarinha quiere sinceramente a su esposo, y es "a mais dócil e afável criatura que por aquêles tempos respirava o ar fluminense." 12

En el cuento "Un Esqueleto", publicado en 1875, el supuesto narrador de la historia explica, al final, que todo ha sido inventado por él mismo con el propósito de distraer a los amigos. La historia trata de un sujeto fańtástico y estrafalario, el Dr. Belém, que en una caja de vidrio conserva el esqueleto de su esposa fallecida. El Dr. Beléin decide contraer segundas nupcias con una joven viuda, y el matrimonio se realiza sin dificultad. Después de algunas semanas de felicidad conyugal, un amigo del Dr. Belém nota cierto aire de tristeza en la recién casada. Un día entra en la casa mientras la pareja está almorzando y ve que el esqueleto está también sentado a la mesa. El doctor aclara que le agrada comer con sus dos esposas, y más tarde explica por qué guarda un objeto tan macabro en su casa. Relata cómo él mismo mató a su primera esposa porque alguien le insinuó que tenía un amante. Sin haber obtenido pruebas definitivas y sin oír a la esposa que juraba su inocencia, ciego de rabia, puso fin a su vida. Después de haber vengado en esta forma su supuesto mancillado honor, comprobó la inocencia de su esposa. Sin embargo, los celos son en él una pasión tan avasalladora, que aunque sabe ahora que su primera esposa era inocente y que su muerte fuè un asesinato sin razón, está usando el esqueleto para advertirle a su actual compañera que ella correrá la misma suerte dado el caso de que se encuentre en la misma situación:

-E simples, continuou êle; é para que minha segunda mulher esteja sempre ao pé da minha vítima, a fim de que se não esqueça nunca dos seus deveres, porque, então como sempre, é mui provável que eu não procure apurar a verdade; farei justiça por minhas mãos. ${ }^{13}$

11 Ibid., p. 221.

12 Ibid, p. 217.

1. Machado de Assis, "Um Esqueleto", Outros Contos, Obra Completa, II (Rio de Janeiro: Editôra José Aguilar Ltda., 1962), p. 823. 
Algún tiempo después el Dr. Belém hace una expedición al interior del país y deja a su esposa en casa de la hermana de su amigo. Al cabo de un mes los llama y les pide que le lleven el esqueleto. El doctor recibe a su esposa con una acusación de infidelidad y le muestra un anónimo que habla de amores entre ella y el amigo. A pesar de la pasada promesa de matar a su presente esposa, decide que esta vez será él el que desaparecerá. Negándose a oír las explicaciones y ruegos de la mujer inocente y del amigo, el Dr. Belém, abrazado al esqueleto, se pierde en la floresta de la selva para nunca más volver.

Si nos parece fatal el resultado de los celos del Dr. Belém, examinemos otro cuento, "Sem Olhos," publicado en 1876. Damasceno, un hombre que vive en completo aislamiento en el piso superior de una casa, cae un día gravemente enfermo. El narrador, un estudiante que vive en otro piso de la misma casa, se interesa por este hombre tan singular, y decide cuidarlo. Damasceno rehusa tomar medicinas e in siste en que su enfermedad es del alma, no del cuerpo. Atormentado por un recuerdo terrible y sintiendo que su fin está próximo, el enfermo relata los motivos de su pena al joven estudiante que ha decidids pasar la noche a su lado. Le cuenta que en su juventud conoció a una mujer bella y modesta, casada con un hombre extremadamente severo y celoso:

Ele era sábio, taciturno e ciumento. Havia nela tanta modéstia e recato, - talvez mêdo,- que o ciúme dêle podia dormir com as portas abertas. Mas não era assim; o matido era cauteloso e suspeitoso; ameaçava-a e fazia-a padecer. ${ }^{14}$

La joven vivía aterrada con la actitud del marido que la amenazaba constantemente. Nunca hablaba con nadie y cuando cambiaba palabra con Damasceno, amigo de su marido, lo hacía con monosílabos y de ojos bajos. Esa misma situación produce resultados adversos, y Damasceno, viendo padecer a la bella joven, pasa de la compasión al amor Un día, viéndola más triste que de costumbre, indaga la causa y ella levanta hacia él su mirada:

...Lucinda estremeceu, e levantou os olhos para mim. Cruzaramse con os meus, mas disseram nesse único minuto-que digo? nesse único instante, tôda a devastação de nossas almas..$^{15}$

14 Machado de Assis, "Sem Olhos", Reliquias de Casa Velba, II (São Paulo: Editôra Mérito, S. A., 1962), p. 111.

15 Ibid., p. 112. 
Desgraciadamente, el marido aparece en ese mismo instante:

Nunca vi mais terrível expresão em rostro humano! A cólera fazia dêle uma Medusa. ${ }^{16}$

Damasceno se va, no sin antes jurar la inocencia de Lucinda. Varias semanas después, oyendo rumores de que la joven está o muerta o gravemente enferma, se dirige a la casa del matrimonio. El marido lo recibe contento y explica que ha castigado como era debido la mirada pecaminosa de Lucinda. Lo conduce al cuarto de la joven que gemía, a las puertas de la muerte:

Vê, disse êle, -só the castiguei os olhos. O espetáculo que ss me revelou então, nunca, oh! nunca mais o esquecerei! Os olhos da pobre moça tinham desaparecido; êle os vazara, na véspera, com um ferro em brasa... Recuei espavorido. $O$ médico apertoume os pulsos clamando com tôda a raiva concentrada em seu coração: "Os olhos delinqüiram, os olhos pagaram!"17.

El narrador aclara aquí que nunca pudo comprobar la veracidad de esta historia, y sugiere que tal vez fuera un producto de la mente alucinada del enfermo. En estos dos últimos cuentos nos presenta Machado de Assis los casos más extremos en dos maridos completamente obcecados por los celos, por cuya causa ejecutan terribles venganzas en sus inocentes esposas. Es posible que, para suavizar el choque y disminuir las protestas que semejantes extremos podrían ocasionar en algunos lectores, Machado recurriera a esta manera de finalizar la historia, explicando la poca veracidad de los relatos.

Es de notar asimismo que todos los protagonistas de estos cuentos, es decir, los personajes aquejados por esta pasión exagerada, son hombres. Esta circunstancia nos proporciona una prueba más de la percepción y del entendimiento del alma y de la mente humana que tenía Machado de Assis. Veamos lo que dicen A. A. Stone y S. S. Stone

One form of paranoid sympton that is common enough to deserve separate consideration is paranoid jealousy. Somewhat more common in men than in women, the condition involves a nearly total preoccupation with the fidelity of the spouse. The afflicted man 
is obsessed by fantasies in which he imagines his wife in the arms of another man. Every shred of evidence that his wife even thinks of another man are seized on, exaggerated, and reacted to as if they were consummated acts of infidelity. Freud has done much to explain this condition. Psychoanalysis of patients who suffered from it revealed a strong undercurrent of latent homosexuality. Their jealousy was a way of displacing their own unacceptable sexual fantasies into their wives. Thus they blamed their wives for their own unconscious sexual impulses. ${ }^{18}$

Machado de Assis tal vez no se percataría del alcance psicológico de sus creaciones; no obstante, el párrafo anterior parece casi un resumen de los acontecimientos que se desarrollan y de los personajes que nos presenta en estos cuentos, y que culminan con Dom Casmurro, su obra maestra, escrita treinta y dos años después de su historia "A Mulher de Prêto," cuando comenzaba la centuria que se distinguiría por los descubrimientos y avances en el estudio de la mente humana.

Southwest Texas State University

María I. Duke dos Santos

${ }_{18}$ Alan A. Stone and Sue Smart Stone, eds., The Abnormal Personality Through Literature (Englewood Cliffs, N. J.: Prentice-Hall Inc., 1966), p. 143. 
